\title{
AMS RADIOCARBON DATING OF THE LARGE PEDUNCULATE OAK OF MERCHEAŞA, ROMANIA
}

\author{
ADRIAN PATRUTTa,b, ${ }^{*}$, LASZLO RAKOSYc, ROXANA T. PATRUT'a, \\ VICTOR BOCOS-BINTINTAN ${ }^{\mathrm{d}}$, ILEANA-ANDREEA RATIU ${ }^{\mathrm{a}, \mathrm{b}}$, \\ JENÖ BODIS ${ }^{\mathrm{a}, \mathrm{b}}$, STEPHAN WOODBORNE
}

\begin{abstract}
The paper reports the AMS (accelerator mass spectrometry) radiocarbon dating results of the large pedunculate oak of Mercheaşa, Romania, which has a circumference of $10.16 \mathrm{~m}$. Two wood samples were extracted from the trunk and from the largest horizontal branch. Five segments from these samples were analysed by AMS radiocarbon. The oldest dated sample segment originates from the largest horizontal branch, very close to its geometrical centre. It had a radiocarbon date of $386 \pm 45 \mathrm{BP}$, which corresponds to a calibrated age of $540 \pm 35$ calendar years. This value indicates an age of $560 \pm 35$ years for the oak of Mercheaşa.
\end{abstract}

Keywords: AMS radiocarbon dating, Quercus robur, dendrochronology, age determination, Romania.

\section{INTRODUCTION}

The pedunculate oak (Quercus robur L.), which belongs to the family Fagaceae, is considered to be one of the most longevous native European trees. This columnar tree is typically $20-30 \mathrm{~m}$ tall, but can reach heights up to 40-50 m, and has a diameter of 3-4 m [1,2]. The largest specimens have died over the last two centuries or are very close to the end of their life cycle. The biggest known individual was the so-called Emperor's Oak (Kaisereiche),

a Babeş-Bolyai University, Faculty of Chemstry and Chemical Engineering, 11 Arany Janos, RO-400028, Cluj-Napoca, Romania

b Babeş-Bolyai University, Raluca Ripan Institute for Research in Chemistry, 30 Fantanele, RO-400294 Cluj-Napoca, Romania

c Babeş-Bolyai University, Faculty of Biology and Geology, 44 Republicii, RO-400015, ClujNapoca, Romania

d Babeş-Bolyai University, Faculty of Envoronmental Science and Engineering, 30 Fantanele, RO-400294 Cluj-Napoca, Romania

e iThemba LABS, Private Bag 11, WITS 2050, South Africa

* Corresponding author: apatrut@gmail.com 
located in the village Randovici, close to Travnik in Bosnia. This giant oak toppled and died in 1998, during a storm. Its enormous hollow trunk, in which 66 infantrymen took shelter, had a circumference at breast height of almost $17 \mathrm{~m}$. Recent research, based on ring counting and also on radiocarbon dating results of long cores, as well as on successive measurements of the circumference over longer periods of time, estimate the age limit of the largest oaks to $600-800$ years, reaching up to 1,000 years only in exceptional cases, considerably less than previously considered [3].

In 2005, we initiated a research project for clarifying several controversial aspects regarding the architecture, growth and age of the African baobab and of other baobab species. The research based on our new approach is not limited to dead or fallen trees, but also enables to investigate and date standing live specimens. This approach consists of AMS radiocarbon dating of tiny wood samples collected from different areas of monumental baobabs [4-9]. We extended our research by investigating individuals which belong to other angiosperm species, including trees from Romania.

Romania hosts several monumental trees of large dimensions and old ages. We investigated and dated by radiocarbon some remains of the historic pedunculate oak of Tebea [10], the large pedunculate oaks of Cajvana and Botoşana [11,12], the old black poplar of Mocod and the very big grey poplar of Rafaila [13], as well as the old ash of Aiton [14].

Here we present the investigation and AMS radiocarbon dating results of another very large Romanian tree, namely the pedunculate oak of Mercheaşa.

\section{RESULTS AND DISCUSSION}

The pedunculate oak of Mercheaşa and its area. The large tree can be found on a pasture with secular oaks, located on a hill at $1.7 \mathrm{~km} \mathrm{NE}$ from the village Mercheaşa, commune Homorod, Braşov county, in the central part of Romania. The closest notable localities are Rupea (at $11 \mathrm{~km}$ ), Sighişoara (55 km) and Braşov (65 km). Its GPS coordinates are 4603.963' N, $025^{\circ} 21.730^{\prime} \mathrm{E}$ and the altitude is $528 \mathrm{~m}$. The mean annual rainfall is around $627 \mathrm{~mm}$ (Sibiu station).

The oak of Mercheaşa has a height of $17.6 \mathrm{~m}$, the circumference at breast height (cbh; at $1.30 \mathrm{~m}$ above mean ground level) is $10.16 \mathrm{~m}$, while the circumference at ground level is $12.08 \mathrm{~m}$. The overall wood volume is around $50 \mathrm{~m}^{3}$, out of which $30 \mathrm{~m}^{3}$ for the trunk and $20 \mathrm{~m}^{3}$ for the crown (Figure 1). 


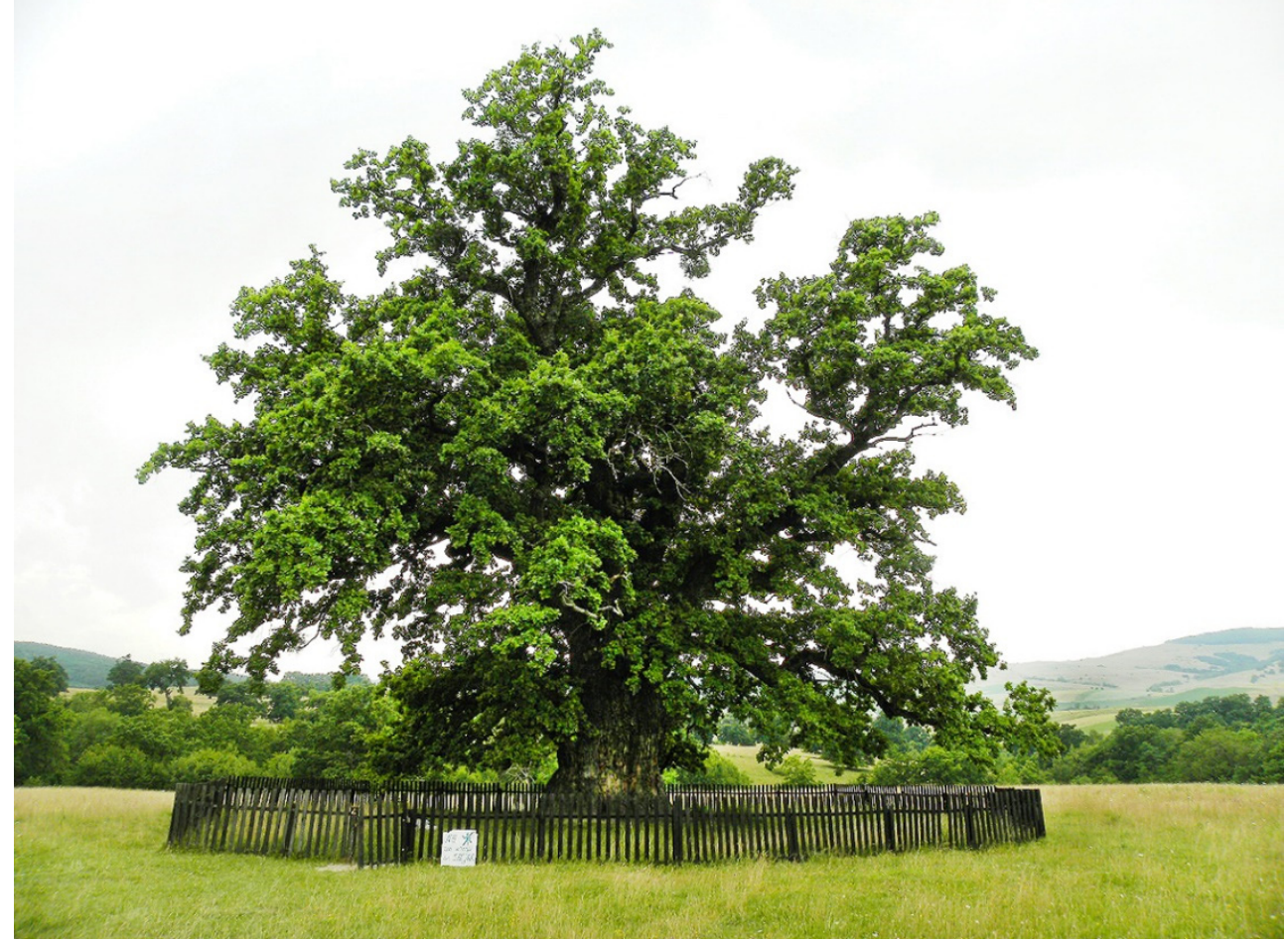

Figure 1. General view of the pedunulate oak of Mercheaşa taken from the south-east.

The canopy is asymmetrical. While its eastern part is higher and narrower, the western part is shorter and wider. The horizontal dimensions of the canopy are 19.7 (NS) $\times 24.4$ (WE) m (Figure 2).

In 2010 , the very large oak was measured and identified by two young students from Rupea as the biggest tree of the pasture, which covers an area of $3 \mathrm{~km}^{2}$. Certain forest engineers estimated the age of this oak to at least 900 years, according to a supposed relationship between the circumference of the trunk and the age of the tree. We want to emphasize that this relationship between circumference and age is based rather on guesstimates than on accepted scientific measurements [15].

In 2012, the oak of Mercheaşa was declared a Natural Monument in a protected area. The same year, a wooden fence was placed around it as a protection measure against animals. At the moment, the Carpaterra Association and ICAS Braşov manage its protection and promotion.

The claimed age value of at least 900 years has been intensely publicised and accepted without reservation. Dozens of visitors from all over the country come daily to the pasture of Mercheaşa to see "the oldest tree of Romania", which was also named "The Carpathian Elder" (Bătrânul Carpaţilor). 


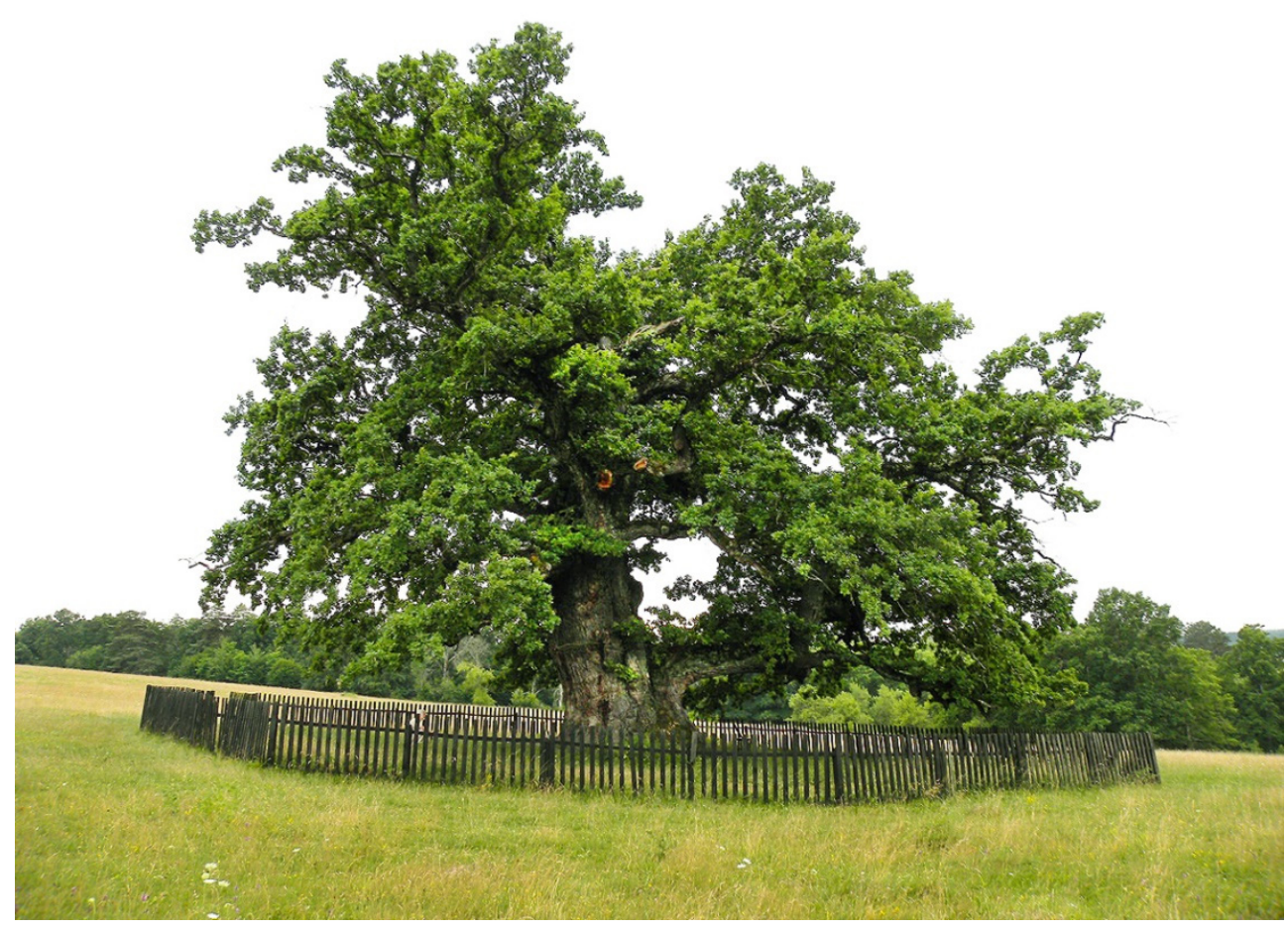

Figure 2. The photograph shows the asymmetrical crown of the oak of Mercheaşa.

The oak of Mercheaşa is in an excellent state of vegetation, with few broken or dry branches and some traces of previous fire damage. The large trunk has no visible cavities. All these data suggest that the oak is considerably younger than currently believed. For these reasons we decided to determine the age of the oak by scientific methods.

Wood samples. Two wood samples, labelled M-1 and M-2, were extracted from the oak of Mercheaşa with an increment borer. The first wood sample $\mathrm{M}-1$, with the length of $0.80 \mathrm{~m}$, was collected from the big trunk, at a convenient height of $1.70 \mathrm{~m}$ above ground. The second sample M-2, with the length of $0.46 \mathrm{~m}$, was collected close to the base of the largest horizontal branch, at a height of $2.10 \mathrm{~m}$ above ground (Figure 3 ).

Two pieces/segments, each of the length of $10^{-3} \mathrm{~m}$ (marked $\mathrm{a}$ and $\mathrm{b}$ ), were extracted from determined positions of the sample $M-1$, while three segments of the same length (marked $a, b$ and $c$ ), were extracted from sample M-2. 


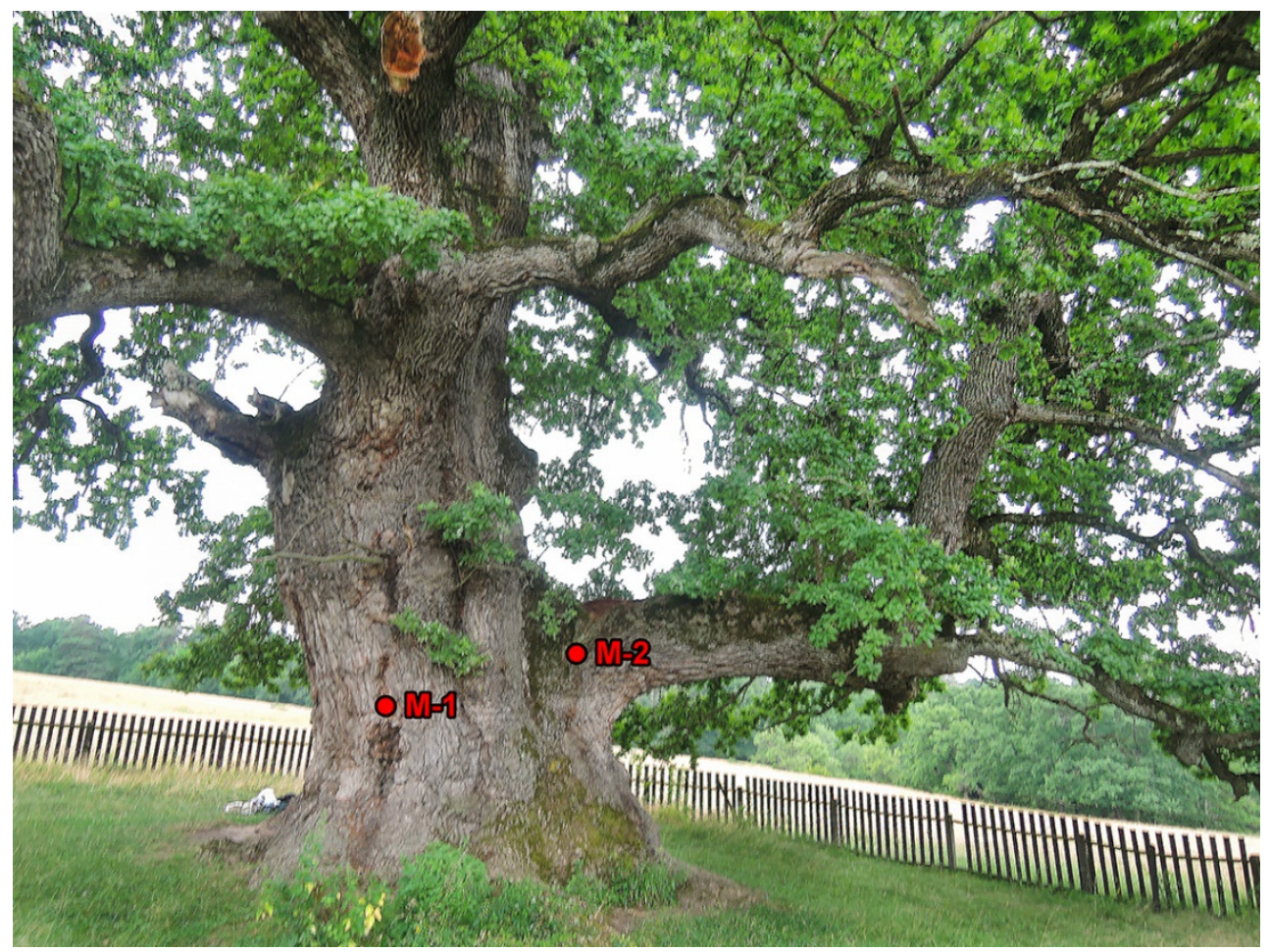

Figure 3. The image presents the two sampling positions.

AMS results and calibrated ages. Radiocarbon dates of the 5 sample segments are listed in Table 1. The radiocarbon dates are expressed in ${ }^{14} \mathrm{C}$ yr BP (radiocarbon years before present, i.e., before the reference year 1950). Radiocarbon dates and errors were rounded to the nearest year.

Calibrated (cal) ages, expressed in calendar years CE (CE, i.e., common era), are also displayed in Table 1 . The $1 \sigma$ probability distribution $(68.3 \%)$ was selected to derive calibrated age ranges. For three segments $(\mathrm{M}-1 \mathrm{a}, \mathrm{M}-2 \mathrm{a}, \mathrm{M}-2 \mathrm{c})$, the $1 \sigma$ distribution is consistent with two ranges of calendar years, while for the other two sample segments (M-1b, M-2b) it corresponds to three ranges of calendar years. In all these cases, the confidence interval of one range is considerably greater than that of the other(s); therefore, it was selected as the cal CE range of the segment for the purpose of this discussion.

For obtaining single calendar age values of sample segments, we derived a mean calendar age of each sample segment from the selected range (marked in bold). Sample/segment ages represent the difference between the year 2021 CE and the mean value of the selected range, with 
ADRIAN PATRUT, LASZLO RAKOSY, ROXANA T. PATRUT, VICTOR BOCOS-BINTINTAN, ILEANA-ANDREEA RATIU, JENÖ BODIS, STEPHAN WOODBORNE

the corresponding error. Sample ages and errors were rounded to the nearest $5 \mathrm{yr}$. We used this approach for selecting calibrated age ranges and single values for sample ages in all our previous articles on AMS radiocarbon dating of large and old angiosperm trees [4-14,15-19].

Table 1. AMS Radiocarbon dating results and calibrated ages of samples collected from the oak of Mercheaşa.

\begin{tabular}{|c|c|c|c|c|c|}
\hline $\begin{array}{l}\text { Sample } \\
\text { code }\end{array}$ & $\begin{array}{c}\text { Depth }^{1} \\
\text { [height } \\
\text { (m) }\end{array}$ & $\begin{array}{c}\text { Radiocarbon } \\
\text { date [error] } \\
\left({ }^{14} \mathrm{C} \text { yr BP }\right)\end{array}$ & $\begin{array}{c}\text { Cal CE range } 1 \sigma \\
\text { [confidence } \\
\text { interval] }\end{array}$ & $\begin{array}{c}\text { Assigned } \\
\text { year } \\
\text { [error] } \\
\text { (cal CE) }\end{array}$ & $\begin{array}{c}\text { Sample } \\
\text { age } \\
\text { [error] } \\
\text { (cal CE) }\end{array}$ \\
\hline M-1a & $\begin{array}{c}0.40 \\
{[1.70]}\end{array}$ & $101[ \pm 44]$ & $\begin{array}{l}1694-1725(16.4 \%) \\
\mathbf{1 8 1 2 - 1 9 1 6}(\mathbf{5 1 . 9 \% )}\end{array}$ & $\begin{array}{c}1864 \\
{[ \pm 52]}\end{array}$ & $\begin{array}{c}155 \\
{[ \pm 50]}\end{array}$ \\
\hline$M-1 b$ & $\begin{array}{c}0.80 \\
{[1.70]}\end{array}$ & $235[ \pm 37]$ & $\begin{array}{c}\mathbf{1 6 3 6 - 1 6 7 8 ( 3 6 . 8 \% )} \\
1741-1752(4.5 \%) \\
1763-1800(27.0 \%)\end{array}$ & $\begin{array}{c}1657 \\
{[ \pm 21]}\end{array}$ & $\begin{array}{c}365 \\
{[ \pm 20]}\end{array}$ \\
\hline $\mathrm{M}-2 \mathrm{a}$ & $\begin{array}{c}0.10 \\
{[2.10]}\end{array}$ & $92[ \pm 43]$ & $\begin{array}{l}1694-1725(17.3 \%) \\
1812-1916(50.9 \%)\end{array}$ & $\begin{array}{c}1864 \\
{[ \pm 52]}\end{array}$ & $\begin{array}{c}155 \\
{[ \pm 50]}\end{array}$ \\
\hline$M-2 b$ & $\begin{array}{c}0.30 \\
{[1.71]}\end{array}$ & $212[ \pm 40]$ & $\begin{array}{c}1647-1682(22.7 \%) \\
1735-1803(38.0 \%) \\
1930-\ldots(8.8 \%)\end{array}$ & $\begin{array}{c}1769 \\
{[ \pm 34]}\end{array}$ & $\begin{array}{c}250 \\
{[ \pm 35]}\end{array}$ \\
\hline$M-2 c$ & $\begin{array}{c}0.47 \\
{[2.10]}\end{array}$ & $386[ \pm 45]$ & $\begin{array}{l}1450-1516(48.3 \%) \\
1590-1620(20.0 \%)\end{array}$ & $\begin{array}{c}1483 \\
{[ \pm 33]}\end{array}$ & $\begin{array}{c}540 \\
{[ \pm 35]}\end{array}$ \\
\hline
\end{tabular}

${ }^{1}$ Depth in the wood from the sampling point.

2 Height above ground level.

Dating results of samples (segments). The oldest dated segment, i.e., M-2c, represents the deepest end of sample M-2 which was collected from the largest horizontal branch, very close to its geometrical centre in the sampling direction. Its radiocarbon date of $386 \pm 45 \mathrm{BP}$ corresponds to a calibrated age of $540 \pm 35$ calendar yr. The lower ages of the other two segments, namely $\mathrm{M}-2 \mathrm{a}$ and $\mathrm{M}-2 \mathrm{~b}$, are in good agreement with their positions in the branch.

The oldest dated segment extracted from sample $M-1$, collected from the trunk, i.e., $\mathrm{M}-1 \mathrm{~b}$, represents its end and originates from a distance of 0.80 $\mathrm{m}$ from the sampling point. It had a radiocarbon date of $235 \pm 37 \mathrm{BP}$, which corresponds to a calibrated age of $365 \pm 40$ calendar yr.

Ring counting. On the collected wood samples, the growth/annual rings are obvious in certain areas, while in other areas they are faint. The most interesting sample M-2 had a length of $0.47 \mathrm{~m}$ and was collected at a 
height of $2.10 \mathrm{~m}$, close to the base of the largest horizontal branch. At this point, the circumference of the branch is $3.03 \mathrm{~m}$. This value corresponds to a radius of $0.48 \mathrm{~m}$. The distance from the sample end to the centre of the branch, which theoretically corresponds to its maximum age, is of $0.01 \mathrm{~m}$.

According to our counting, sample 2 contains around 520 growth rings. Taking into account the distance from the sample end to the centre of the branch and also the height of the branch above the ground, the ring counting suggests an age of 540 years for the pedunculate oak.

Age of the pedunculate oak of Mercheaşa. The age of the oak can be calculated by extrapolating the age of the oldest dated sample segment M-2c, namely $540 \pm 35$ years, which originates from the largest branch, to the centre of this branch and by considering also the height of the branch. By the already presented values, the radiocarbon dating results indicate an age of $560 \pm 35$ years for the oldest part of the pedunculate oak of Mercheaşa. This value is in good accordance with the age estimated from the ring counting.

\section{CONCLUSIONS}

Our research dicloses the AMS radiocarbon dating results of the large pedunculate oak of Mercheaşa. The aim of our investigation was to determine the age of tree. Two wood samples were collected from the trunk and from the largest horizontal branch, respectively. Five tiny segments were extracted from the samples, processed and dated by AMS radiocarbon.

The oldest dated segment had a radiocarbon date of $386 \pm 45 \mathrm{BP}$, which corresponds to a calibrated age of $540 \pm 35$ calendar years. Its original position is very close to the geometrical centre of the largest horizontal branch. The dating value indicates an age of $560 \pm 35$ years for the oak of Mercheaşa. Therefore, one can state that the oak of Mercheaşa started growing around the year $1460 \mathrm{CE}$.

\section{EXPERIMENTAL SECTION}

Sample collection. The two investigated wood samples were collected with a Haglöf $\mathrm{CH} 800$ increment borer (0.80 m long, $0.0108 \mathrm{~m}$ inner diametre). A number of five tiny pieces/segments, of the length of $10^{-3} \mathrm{~m}$, were extracted from predetermined positions along the samples. The segments were processed and investigated by AMS radiocarbon dating. 
ADRIAN PATRUT, LASZLO RAKOSY, ROXANA T. PATRUT, VICTOR BOCOS-BINTINTAN, ILEANA-ANDREEA RATIU, JENÖ BODIS, STEPHAN WOODBORNE

Sample preparation. The a-cellulose pretreatment method was used for removing soluble and mobile organic components [20]. The resulting samples were combusted to $\mathrm{CO}_{2}$, which was next reduced to graphite on iron catalyst $[21,22]$. The resulting graphite samples were analysed by AMS.

AMS measurements. The radiocarbon measurements were done at the AMS Facility of iThemba LABS, Johannesburg, Gauteng, South Africa, using the 6 MV Tandem AMS system [23]. The obtained fraction modern values were finally converted to a radiocarbon date. The radiocarbon dates and errors were rounded to the nearest year.

Calibration. Radiocarbon dates were calibrated and converted into calendar ages with the OxCal v4.4 for Windows [24], by using the IntCal20 atmospheric data set [25].

\section{ACKNOWLEDGMENTS}

The research was funded by the Romanian Ministry of Education CNCS-UEFISCDI under grant PN-III-P4-ID-PCE-2020-2567, No. 145/2021.

\section{REFERENCES}

1. P.H. Raven, G.B. Johnson, J.B. Losos, S.R. Singer, "Biology: Seventh Edition", McGraw Hill, New York, 2005.

2. A. le Hardÿ de Beaulieu, T. Lamant, "Le guide illustré des chênes", Vol. 1-2, Huitième, Paris, 2007.

3. J. Pater, "Riesige Eichen: Baumpersönlichkeiten und ihre Geschichten", FranckhKosmos, Stuttgart, 2017.

4. A. Patrut, K.F. von Reden, D.A. Lowy, A.H. Alberts, J.W. Pohlman, R. Wittmann, D. Gerlach, L. Xu, C. Mitchell, Tree Phys., 2007, 27, 1569-1574.

5. A. Patrut, K.F. von Reden, R. Van Pelt, D.H. Mayne, D.A. Lowy, D. Margineanu, Ann. Forest Sci., 2011, 68, 993-1003.

6. A. Patrut, S. Woodborne, K.F. von Reden, G. Hall, M. Hofmeyr, D. Lowy, R.T. Patrut, PLOS ONE, 2015, 10(1), e0117193.

7. A. Patrut, L. Rakosy, R.T. Patrut, I.A. Ratiu, E. Forizs, D.A. Lowy, D. Margineanu, K.F. von Reden, Studia UBB Chemia, 2016, LXI, 4, 7-20.

8. A. Patrut, S. Woodborne, K.F. von Reden, G. Hall, R.T. Patrut, L. Rakosy, P. Danthu, J-M. Leong Pock-Tsy, D.A. Lowy, D. Margineanu, Radiocarbon, 2017, 59(2), 435-448.

9. A. Patrut, S. Woodborne, R.T. Patrut, L. Rakosy, D.A. Lowy, G. Hall, K.F. von

Reden, Nat. Plants, 2018, 4, 423-426. 
10. A. Patrut, K.F. von Reden, D.A. Lowy, S. Pasca, L. Kekedy-Nagy, I. Sovago, Studia UBB Chemia, 2010, LV, 1, 113-120.

11. A. Patrut, K.F. von Reden, V. Savu, D.A. Lowy, R. Mitea, I. Barbul, Studia UBB Chemia, 2011, LVI, 1, 145-155.

12. A. Patrut, N. Robu, V. Savu, R.T. Patrut, L. Rakosy, I.A. Ratiu, D.A. Lowy, D. Margineanu, K.F. von Reden, Studia UBB Chemia, 2018, LXIII, 4, 7-13.

13. A. Patrut, K.F. von Reden, D.A. Lowy, R.T. Patrut, D.L. Vaida, D. Margineanu, Nucl. Instrum. Methods Phys. Res. Sect. B., 2013, 294, 616-621.

14. A. Patrut, R.T. Patrut, L. Rakosy, I.A. Ratiu, D.A. Lowy, J. Bodis, K.F. von Reden, Studia UBB Chemia, 2018, LXIII, 3, 41-48.

15. Institutul de cercetări şi amenajări silvice Braşov, Asociaţia Geopark Perşani, "Stejarul secular din Mercheaşa - Bătrânul Carpaţilor (Studiu de fundamentare ştiinţifică pentru declararea Monumentului Naturii)", Braşov, 2011.

16. A. Patrut, A. Garg, S. Woodborne, R.T. Patrut, L. Rakosy, I.A. Ratiu, PLOS One, 2020, 15(1): e0227352.

17. A. Patrut, K.F. von Reden, P. Danthu, J-M. Leong Pock-Tsy, L. Rakosy, R.T. Patrut, D.A. Lowy, D. Margineanu, Nucl. Instrum. Methods Phys. Res. Sect. B, 2015, 361, 591-598.

18. A. Patrut, R.T.Patrut, L. Rakosy, D.A. Lowy, D. Margineanu, K.F. von Reden, Studia UBB Chemia, 2019, LXIV, 2 (II), 411-419.

19. A. Patrut, R.T. Patrut, P. Danthu, J-M. Leong Pock-Tsy, L. Rakosy, D.A. Lowy, K.F. von Reden, PLOS One, 2016, 11(1): e0146977.

20. N.J. Loader, I. Robertson, A.C. Barker, V.R. Switsur, J.S. Waterhouse, Chem. Geol.,1997, 136(3), 313-317.

21. Z. Sofer, Anal. Chem., 1980, 52(8), 1389-1391.

22. J.S. Vogel, J.R. Southon, D.E. Nelson, T.A. Brown, Nucl. Instrum. Methods Phys. Res. Sect. B, 1984, 5, 289-293.

23. V.L. Mbele, S.M. Mullins, S.R. Winkler, S. Woodborne, Phys. Procedia, 2017, 90, 10-16.

24. C. Bronk Ramsey, Radiocarbon, 2009, 51, 337-360.

25. P.J. Reimer, W.E. N. Austin, E. Bard, A. Bayliss, P.G. Blackwell, C. Bronk Ramsey, M. Butzin, H. Cheng, R. Lawrence Edwards, M. Friedrich, P.M. Grootes, T.P. Guilderson, I. Hajdas, T.J. Heaton, A. G. Hogg, K.A Hughen, B. Kromer, S.W. Manning, R. Muscheler, J.G. Palmer, C. Pearson, J. van der Plicht, R.W. Reimer, D.A. Richards, E.M. Scott, J.R. Southon, C.S.M. Turney, L. Wacker, F. Adolphi, U. Büntgen, M. Capano, S.M. Fahrni, A. Fogtmann-Schulz, R. Friedrich, P. Köhler, S. Kudsk, F. Miyake, J. Olsen, F. Reinig, M. Sakamoto, A. Sookdeo, S. Talamo, Radiocarbon, 2020, 62(4), 727-757. 